\title{
Immunological Challenges and Therapies in Xenotransplantation
}

\author{
Marta Vadori ${ }^{1}$ and Emanuele Cozzi ${ }^{1,2,3}$ \\ ${ }^{1}$ CORIT (Consortium for Research in Organ Transplantation), Legnaro, 35020 Padua, Italy \\ ${ }^{2}$ Transplant Immunology Unit, Padua University Hospital, 35128 Padua, Italy \\ ${ }^{3}$ Department of Surgical, Oncological and Gastroenterological Sciences, University of Padua, \\ Ospedale Giustinianeo, 35128 Padua, Italy \\ Correspondence: emanuele.cozzi@unipd.it
}

\begin{abstract}
Xenotransplantation, or the transplantation of cells, tissues, or organs between different species, was proposed a long time ago as a possible solution to the worldwide shortage of human organs and tissues for transplantation. In this setting, the pig is currently seen as the most likely candidate species. In the last decade, progress in this field has been remarkable and includes a better insight into the immunological mechanisms underlying the rejection process. Several immunological hurdles nonetheless remain, such as the strong antibodymediated and innate or adaptive cellular immune responses linked to coagulation derangements, precluding indefinite xenograft survival. This article reviews our current understanding of the immunological mechanisms involved in xenograft rejection and the potential strategies that may enable xenotransplantation to become a clinical reality in the not-toodistant future.
\end{abstract}

$\mathrm{B}$ "xenotransplantation," we conventionally refer to the transplantation of cells, tissues, or organs from one species to another. Current interest in xenotransplantation stems from the worldwide shortage of human organs, tissues, and cells for use in clinical transplantation. At least in theory, the imbalance between supply and demand could be wholly addressed if organs, tissues, or cells from other species could be transplanted into humans. The pig is currently considered the most appropriate candidate species because of its anatomical similarity, physiological compatibility, breeding characteristics, and for ethical reasons. Ongoing preclinical research in this field is consequently based on the use of pigs as donors and nonhuman primates as recipient species.

By now, we have gained a significant insight into the immunological processes underlying the rejection of porcine xenografts transplanted into primates. Considerable advances have also been made to elucidate the dysregulated coagulation occurring after porcine xenografts have been transplanted into primates. Despite the encouraging results obtained to date, especially in the field of cell xenotransplantation, several issues nonetheless remain to be addressed before any clinical application of xenotransplantation can proceed.

Editors: Laurence A. Turka and Kathryn J. Wood

Additional Perspectives on Transplantation available at www.perspectivesinmedicine.org

Copyright (C) 2014 Cold Spring Harbor Laboratory Press; all rights reserved; doi: 10.1101/cshperspect.a015578

Cite this article as Cold Spring Harb Perspect Med 2014;4:a015578 
This review summarizes current knowledge in this field, focusing exclusively on the immune mechanisms underlying the rejection of cardiac, renal, and islet xenografts, and on possible strategies to overcome these obstacles. The main emphasis is placed on the most clinically relevant pig-to-primate models. A comprehensive, accurate analysis of the coagulation derangements associated with xenotransplantation would be too lengthy for the format of this monograph; thus, for the sake of brevity, the reader is referred to other, excellent reviews recently published on the subject (Lin et al. 2009; Schmelzle et al. 2010; Cowan et al. 2011; Bulato et al. 2012).

\section{MECHANISMS UNDERLYING XENOGRAFT REJECTION}

\section{Antibody-Mediated Xenograft Rejection}

The rejection of a xenografted solid organ is characterized primarily by a picture compatible with a humorally driven immunological process. The humoral component of the immune response is a formidable barrier to short- and long-term organ survival. Hyperacute rejection (HAR) and acute humoral xenograft rejection (AHXR), also termed delayed xenograft rejection, are the main features of the humorally mediated xenograft rejection occurring when pig organs are transplanted into untreated primates.

HAR is a rapid, powerful process involving diffuse interstitial hemorrhage, edema, and thrombosis of the small vessels (Stevens and Platt 1992). This process is triggered by preexisting antibodies binding to xenograft antigens and prompting complement activation, graft endothelial cell activation and destruction, activation of the coagulation cascade, and graft rejection within minutes or hours. Preformed antipig antibodies are believed to be directed primarily against the terminal $\alpha 3$-galactose of the $\mathrm{N}$-acetyllactosamine in glycoprotein and glycolipid carbohydrate chains (Gal$\alpha 3 \mathrm{Gal} \beta 4 \mathrm{Glc}-\mathrm{Nac}-\mathrm{R}$ or $\alpha \mathrm{Gal}$ epitope) (Galili et al. 1988; Macher and Galili 2008). The synthesis of $\alpha \mathrm{Gal}$ is catalyzed by the $\alpha 1-3$ galactosyltransferase ( $\alpha 1-3 \mathrm{GalT})$, an enzyme expressed in nonprimate mammals, including the pig and in New World monkeys. The density of $\alpha \mathrm{Gal}$ epitopes in pig organs goes from 1 to $3 \times 10^{7}$ epitopes per cell, in endothelial and epithelial cells, respectively (Galili et al. 1988). These $\alpha \mathrm{Gal}$ epitopes have been identified in decellularized xenogeneic biological scaffolds, like the mammalian extracellular matrix used in surgical reconstructions, even after treatments to remove or mask antigenic epitopes (McPherson et al. 2000; Konakci et al. 2005; Stone et al. 2007). In human beings, and in Old World monkeys and apes, $\alpha 1-3$ GalT is inactive, the $\alpha \mathrm{Gal}$ epitope is not expressed, and there are high titers of anti- $\alpha$ Gal antibodies due to exposure to similar epitopes expressed by bacteria hosted in the gut flora. A significant percentage of preformed total antibodies in human and nonhuman primates reacts with the $\alpha \mathrm{Gal}$ epitope $(1 \%-8 \%$ of total IgM and $1-2.4 \%$ of total IgG) (Parker et al. 1994; McMorrow et al. 1997).

A detailed study to ascertain the nature and residence of cells producing anti- $\alpha \mathrm{Gal}$ antibodies found them located primarily in the spleen, in both naïve and immunized nonhuman primates, and to a lesser extent in the lymph nodes (LN) and bone morrow (BM) (Xu et al. 2006). Splenectomy does not seem to affect the number of cells secreting anti- $\alpha \mathrm{Gal}$ antibodies in the $\mathrm{LN}$ and BM, except in the case of sensitized animals, when exposure to $\alpha \mathrm{Gal}$ considerably increases their number, but only in the BM. The cells that produce anti- $\alpha$ Gal IgM and IgG are the surface Ig-positive B cells and mature plasma cells, respectively. Six months after exposure to porcine tissues or hematopoietic cells, cells secreting anti- $\alpha \mathrm{Gal}$ antibodies mainly produce IgG and are found in the BM as long-lived mature plasma cells.

The humoral response to sugars is primarily T-cell independent, although evidence from several lines of research suggests that natural and elicited anti- $\alpha$ Gal humoral response is primarily T-cell dependent. First, a significantly reduced natural and elicited anti- $\alpha$ Gal IgM were observed in an $\alpha 1-3$ GalT- and TCR- $\beta$ deficient mouse model lacking any $\alpha \mathrm{Gal}$ epitope expression and functional $\alpha \beta \mathrm{T}$ cells, by comparison with mice with normal $\alpha \beta$ T cells (TCR- $\beta^{+}$) (Cretin et al. 2002). Second, blocking 
the CD40/CD154 pathway's interaction between B and T cells with an anti-CD154 agent inhibits the elicited anti- $\alpha$ Gal IgM (Cretin et al. 2002) and IgG (Tanemura et al. 2000) response. Third, immunization with T-cell-independent agents expressing $\alpha \mathrm{Gal}$ epitopes, such as an $\alpha \mathrm{Gal}$ multivalent polyacrylamide polymer (Cretin et al. 2002) or glycolipids ( $\mathrm{Ta}-$ nemura et al. 2000), induces a mild increase in IgM antibodies and no IgG. There is consequently evidence of a limited amount of anti$\alpha$ Gal IgM production occurring via T-cell-independent mechanisms (Tanemura et al. 2000; Cretin et al. 2002). The demonstration that immunizing $\alpha$ GalT-KO mice with pig cell membranes elicits anti- $\alpha \mathrm{Gal} \operatorname{IgM}$ and $\operatorname{IgG}$, induces an expansion of the anti- $\alpha$ Gal $B$ cell clones, and causes a strong in vitro T-cell stimulation even after $\alpha$ Gal expression has been suppressed leads to the hypothesis that xenopeptides bearing $\alpha \mathrm{Gal}$ epitopes are internalized, processed by $\mathrm{B}$ cells, and presented to helper T cells. The resulting activation of helper $\mathrm{T}$ lymphocytes enables the $\mathrm{B}$ cells to complete their activation process, ultimately resulting in proliferation, isotype switching, and the generation of plasma cells and high-affinity anti- $\alpha \mathrm{Gal}$ antibodies (Tanemura et al. 2000). Finally, there are reports of follicular dendritic cells expressing complement receptors 1 and 2 being involved in the presentation of immune complexes to $\alpha \mathrm{Gal}$-reactive B cells and being needed for antigen-specific anti$\alpha \mathrm{Gal}$ response (Shimizu et al. 2007).

At this stage, thanks to the many approaches pursued with a view to removing preexisting anti- $\alpha \mathrm{Gal}$ antibodies and controlling their effector functions, HAR of a solid organ xenograft has become a rare event. Solid organ xenografts are nonetheless still rejected within days or months as a result of AHXR, even when the donor has been genetically engineered and expresses no $\alpha$ Gal epitope (GalT-KO pigs). After the transplantation of GalT-KO kidneys, AHXR is characterized histologically by a thrombotic microangiopathic glomerulopathy with increasing IgM, IgG, C4d, and C5b-9 deposition in the glomeruli, with thrombi forming inside the injured glomeruli, loss of capillaries, and endothelial cell death (Shimizu et al. 2012). A similar picture can be seen after heart xenotransplantation (Shimizu et al. 2008), in which case, AHXR is characterized by antibody and complement deposition on the capillary walls, multiple microthrombi in the capillaries, myocardial ischemia, and necrosis. The pathogenesis of AHXR is assumed to be multifactorial, but preformed and induced antibodies directed against the endothelium are believed to be the primary factors triggering AHXR, resulting in endothelial activation and orienting the anticoagulative properties of the endothelium toward a procoagulative phenotype favoring thrombosis (Crikis et al. 2006).

The damage seen in the AHXR process, and in the thrombotic microangiopathy (TM) occurring even when porcine GalT-KO organs are used, gives the impression that $\alpha \mathrm{Gal}$ epitopes may still be expressed by GalT-KO organs, or else that other antibodies not directed against $\alpha \mathrm{Gal}$ are involved. It has now been shown, in fact, that another enzyme called $\mathrm{iGb}_{3}$ synthase leads to $\alpha$ Gal epitope production in GalT-KO animals (Sharma et al. 2003), although this has not been confirmed by other investigators (Diswall et al. 2010, 2011; Fang et al. 2012; Puga Yung et al. 2012; Tahiri et al. 2013). In any case, the levels of both IgM and IgG anti- $\alpha$ Gal antibodies remain stable after GalT-KO xenografts have been transplanted into nonhuman primates (Chen et al. 2005; Kuwaki et al. 2005), suggesting that-with the coverage afforded by current immunosuppression-any remaining $\alpha \mathrm{Gal}$ epitopes are poorly immunogenic and may not be responsible for any graft damage. In this light, much attention has been paid to the influence of antibodies against non$\alpha$ Gal epitopes on humoral rejection. High levels of natural and elicited IgM and IgG against non$\alpha \mathrm{Gal}$ are detected in xenografted primates and associated with the onset of AHXR, even when the potentially detrimental role of $\alpha \mathrm{Gal}$ antibodies is averted by absorption (Lam et al. 2004; Chen et al. 2006).

In healthy humans, albeit with some interindividual variability, it has been reported that $13 \%$ of $\operatorname{IgM}$ and $36 \%$ of IgG binding to pig endothelial cells are directed against non- $\alpha \mathrm{Gal}$ epitopes, and these antibodies can cause cell 
damage via complement fixation and antibodydependent cell-mediated cytotoxicity (ADCC) (Baumann et al. 2007). Little is known about the kinetics of the anti- $\alpha$ Gal and anti-non$\alpha \mathrm{Gal}$ antibody response elicited in humans. When mouse fibroblasts were injected into humans as part of a gene therapy approach, there was a very rapid and sustained anti- $\alpha \mathrm{Gal}$ antibody response, with a 100 -fold increase in antibody titers that dropped back within the second month, possibly as a consequence of the immunizing fibroblasts being eliminated. As for non- $\alpha \mathrm{Gal}$ antibodies, the immune response elicited took longer and never reached the same levels as the anti- $\alpha \mathrm{Gal}$ antibodies. In another study, pig ligaments lacking any $\alpha \mathrm{Gal}$ epitopes implanted into humans elicited an anti-non$\alpha \mathrm{Gal}$ antibody response directed against both carbohydrate and protein structures (Breimer 2011; Galili 2012). Two months after the ligaments were implanted, there was a rise in non$\alpha \mathrm{Gal} \operatorname{IgG}$ that peaked at $6 \mathrm{mo}$ and decreased thereafter (coinciding with the pig tissue being gradually replaced by recipient collagen), returning to pretransplant levels within $2 \mathrm{yr}$. Like the anti- $\alpha$ Gal antibody response, the natural and elicited response against anti-non$\alpha$ Gal also appears to be T-cell dependent. This hypothesis is supported by the fact that there was no evidence of any elicited anti-non- $\alpha \mathrm{Gal}$ antibody response after blockade of the CD40CD154 activation pathway and no subsequent T-cell help to B lymphocytes (Buhler et al. 2000). Similarly to what happens following the xenografting of wild-type organs, humoral response to GalT-KO pigs is not polyclonal-it is restricted. It is encoded, in this case, by V3-21 germline progenitors in the $\mathrm{V}_{\mathrm{H}^{3}}$ family (Kiernan et al. 2008), an observation that may have therapeutic implications.

With regard to the specificity of anti-non$\alpha \mathrm{Gal}$ antibodies, recent studies have reported that they are directed against carbohydrates (that are distinct from $\alpha \mathrm{Gal}$, although they are structurally related) or proteins. When Yeh et al. (2010) analyzed naïve human or immunized baboon sera, reactivity against a panel of selected synthetic non- $\alpha$ Gal saccharides showed that human and baboon sera contain antisac- charide antibodies directed against several specific entities including $\alpha$ Gal-penta, $\alpha$-LacNAc, Forssman antigen, P1, Pk, and Neu5Gc. There was only a minimal presence of anti- $\beta$-LacNAc antibodies, and this is a very important finding because GalT-KO animals express large amounts of this carbohydrate, appearing de novo as a consequence of $\alpha \mathrm{Gal}$ epitope removal. Such studies were also able to show that pigs do not express the Forssman antigen (a glycolipid against which humans have several antibodies), as shown by the presence of the high levels of anti-Forssman antibodies and the absence of Forssman antigens in pig tissues. Unexpectedly, the same study found that baboons immunized with GalT-KO pig cells had no significantly increased IgM and IgG binding to $\alpha$ Gal-tri, or any of the saccharides in the panel considered, a finding that contrasts with the report from Diswall et al. (2010), who identified a different pattern of glycolipid expression in organs from GalT-KO pigs. The $\mathrm{P}_{1}$ antigen (not seen in wildtype kidneys) was detected in the GalT-KO line, for instance. Similarly, the $\mathrm{X}_{2}$ antigen was found expressed in the heart from the GalT-KO line, but not in the wild-type line analyzed. These antigens should not be seen as novel antigens appearing ex novo in the GalT-KO line, however, because the glycosyltransferases involved (namely, $\alpha 1-4$ galactosyltransferase and $\beta_{1}$, 3 GalNacT) occur naturally in the wild-type line. Deletion of the $\alpha 1-3$ GalT enzyme may, however, have diverted the sugar metabolism toward an increased or de novo expression of these glycolipids in some tissues.

Another set of particularly important target epitopes includes the glycans carrying $\mathrm{N}$-glycolylneuraminic acid (Neu5GC), or the socalled Hanganutziu-Deicher antigen, which is abundantly present in many mammals, including pigs and monkeys, but not in humans (Varki 2010). Healthy humans consequently have a highly variable polyclonal antibody profile against Neu5GC. Natural anti-Neu5GC antibodies are predominantly IgG (Padler-Karavani et al. 2008), but may be IgM and IgA too, albeit to a lesser extent. Anti-Neu5GC can be induced in humans after exposure to porcine tissues (Blixt et al. 2009; Scobie et al. 2013). Nonhuman 
primates express Neu5GC antigens, however, and are unable to elicit a humoral response against this epitope, making their use in relevant preclinical studies unfeasible; hence the development of surrogate rodent models, such as double-KO mice that lack both $\alpha \mathrm{Gal}$ and Neu5GC epitopes as a consequence of GalT and cytidine monophospho- $\mathrm{N}$-acetylneuraminic acid hydrolase (CMAH) inactivation (Basnet et al. 2010). Extensive investigations have shown that anti-Neu5GC antibodies can induce complement-mediated cytotoxicity, albeit to a lesser extent than anti- $\alpha \mathrm{Gal}$ antibodies (Basnet et al. 2010), suggesting that anti-Neu5GC antibodies may be important in eliciting AHXR of GalT-KO organs. This hypothesis is further supported by the recent finding that GalT-KO pigs have an increased Neu5GC production (Park et al. 2011, 2012).

On the matter of xenogeneic proteins, two recent reports have identified several membrane proteins that are recognized by primates rejecting porcine cardiac xenografts. In particular, most recipients' elicited antixenograft repertoire included antibodies directed against fibronectin, several stress response and inflammation proteins, and also proteins involved in key endothelial cell functions (Byrne et al. 2008, 2011). These included proteins involved in regulating inflammation (e.g., annexin A2), hemostasis (e.g., CD9 and endothelial cell protein $\mathrm{C}$ receptor), or the complement cascade (e.g., CD46 and CD59), all potentially important functions in the context of AHXR. In theory at least, such elicited antibodies could block important cell functions, and the researchers speculated that it may be necessary to substitute these key porcine proteins with their human counterpart, instead of eliminating them, if porcine endothelial function needs to remain intact. A recent proteomic analysis identified several immunoreactive membrane proteins on GalT-KO pig liver endothelial cells recognized by natural human IgM and IgG (Burlak et al. 2012), and the investigators suggested that more than 800 different proteins may be recognized by preexisting IgG and/or IgM in human sera. However, they were unable to establish unequivocally whether antibodies bind to different proteins or to a limited number of carbohydrate epitopes expressed by a large number of different proteins.

Many groups have shown that the swine major histocompatibility complex (SLA) is recognized by anti-HLA antibodies in the sera of sensitized patients (Naziruddin et al. 1998; Diaz Varela et al. 2003), and that these antibodies may be cytotoxic to pig cells (Taylor et al. 1998; Mulder et al.2010). The cross-reactivity between human and pig anti-MHC antibodies may be due to MHC epitopes conserved between the two species (Mulder et al. 2010). For a future clinical application of xenotransplantation, it may therefore be essential to select the most appropriate, matched donor pig haplotype.

\section{Cell-Mediated Xenograft Rejection}

\section{The Role of T Lymphocytes}

Although natural and elicited antibody responses have so far been considered the main barrier to successful xenotransplantation, the involvement of T cells in xenograft rejection has yet to be fully clarified. T cells contribute to the induction of antidonor antibodies, but it has not yet been unequivocally shown whether T cells alone are capable of mediating xenograft rejection.

T-cell antixenograft immune response was studied first in vitro (Yamada et al. 1995; Dorling et al. 1996), and it was found that T-cell responses against pig xenografts could be at least as strong as in the allotransplantation setting (Yamada et al. 1995; Lin et al. 2008). These studies showed that, as in the allogeneic response, human $\mathrm{T}$ cells are able to recognize porcine MHC molecules via direct and indirect recognition pathways (Yamada et al. 1995; Dorling et al. 1996). Direct T-cell xenoresponses accounted for $>75 \%$ of the xenodirected lymphocyte response observed in mixed lymphocyte reaction (MLR) studies (Yamada et al. 1995; Tahara et al. 2010) and were mediated mainly by $\mathrm{CD} 4^{+}$cells directed primarily against SLADR, but also against SLA-DQ molecules (Yamada et al. 1995; Dorling et al. 1996). In contrast, the same researchers reported little to no direct recognition of SLA class I antigens by $\mathrm{CD}^{+}$human T cells. The strong direct T-cell reaction is 
not due to a higher frequency of human xenoreactive $\mathrm{CD}^{+}{ }^{+} \mathrm{T}$ cells than in the allogeneic counterpart, and there was no evidence of any differences in $\mathrm{CD}^{+}{ }^{+} \mathrm{T}$-cell content between alloand xenorelated direct reactions (Tahara et al. 2010). These studies also suggest that the CD4 ${ }^{+}$ helper function is needed for xenoreactive $\mathrm{CD}^{+}{ }^{+} \mathrm{T}$ cells to proliferate (Tahara et al. 2010). Indirect antipig $\mathrm{T}$-cell responses appear to be mediated primarily by $\mathrm{CD} 4^{+} \mathrm{T}$ cells (Dorling et al. 1996). The indirect antixenograft response is stronger than in the allogeneic counterpart, possibly because of the larger number of xenogeneic peptides presented by human antigenpresenting cells (Dorling et al. 1996).

As in allotransplantation, costimulatory signals are needed to fully activate the antixenograft T-cell responses via both direct and indirect pathways. In particular, CD40 and CD80/ CD86 on antigen-presenting cells must interact with CD154 (CD40 L) and CD28 or cytotoxic Tlymphocyte antigen-4 (CTLA-4) on T cells. Extensive studies conducted by Rogers et al. (2003) have shown that porcine CD40, CD80, and CD86 are independently capable of costimulating human $\mathrm{CD} 4{ }^{+}$cells efficiently, albeit via different kinetics. In particular, porcine endothelial cells constitutively express CD80/CD86 (Koshika et al. 2011) and SLA class I, and possibly class II molecules as well (Choo et al. 1997). Porcine endothelial cells also trigger a direct, MHC-restricted CD8 ${ }^{+}$T- and CD4 ${ }^{+}$T-cell activation (Yamada et al. 1995; Dorling and Lechler 1998; Kim et al. 2010; Koshika et al. 2011; Wilhite et al. 2012). High levels of cytotoxicity have also been detected, mediated mainly by $\mathrm{CD}^{+}{ }^{+} \mathrm{T}$ cells, but also by $\mathrm{CD} 8^{+} \mathrm{T}$ cells.

Analyzing in vitro lymphocyte proliferation induced by wild-type or GalT-KO endothelial cell shows that $\alpha \mathrm{Gal}$ epitope expression on the endothelium is associated with a greater proliferation of $\mathrm{CD}^{+}$and $\mathrm{CD}^{+} \mathrm{T}$ cells (Lin et al. 2008; Wilhite et al. 2012), suggesting an as-yetunidentified role of $\alpha \mathrm{Gal}$ epitopes in sustaining $\mathrm{T}$ cell response. The absence of $\alpha \mathrm{Gal}$ is also associated with a significantly reduced secretion of INF- $\gamma$, TNF- $\alpha$, IL-17A by CD $4{ }^{+}$T cells, and of INF- $\gamma$, granzyme-B, and the chemokine IP10 by $\mathrm{CD}^{+} \mathrm{T}$ cells (Wilhite et al. 2012), par- tially confirming earlier findings reported by Saethre et al. (2008), who showed that exposure to $\mathrm{Gal}^{+/+}$endothelial cells was associated with a significant release of human INF- $\gamma$, human and porcine proinflammatory IL-6 and IL-8, and several human $\beta$ chemokines, whereas this picture was not seen after exposure to $\mathrm{Gal}^{-/-}$cells (Saethre et al. 2008). Unlike the report from Wilhite et al. (2012), however, the T-cell-recruiting $\alpha$-chemokine IP-10 in the Saethre study was induced in cells lacking the $\alpha \mathrm{Gal}$ epitopes. Complement inhibition with Compstatin (a C3 inhibitor) or C5aR (a C5a antagonist) was able to abolish the production of human cytokines and chemokines, with the exception of the $\alpha$-chemokine IP-10. Following exposure to human whole blood, $\mathrm{Gal}^{+/+}$(but not $\mathrm{Gal}^{-/-}$) endothelial cells release porcine IL-6 and IL-8, a phenomenon that could be abolished by Compstatin. Taken together, these findings show the important role of the $\alpha \mathrm{Gal}$ epitope in the production of proinflammatory cytokines by human blood cells, as well as the central role of complement in mediating human immune effector functions and porcine cell activation. Recent evidence of a complement-induced T-cell and APC activation should also be borne in mind and warrants further analysis (Kwan et al. 2012).

Different cell infiltration patterns have been described after pig-to-primate solid organ xenotransplantation. In most cases, $\mathrm{CD}^{+} \mathrm{T}$ cells with monocytes/macrophages, B cells, and some NK cells were the predominant cells detected in the graft at euthanasia (Ashton-Chess et al. 2003; Cozzi et al. 2003; Shimizu et al. 2012). $\mathrm{CD}^{+} \mathrm{T}$ cells were only reported in a limited number of cases (Davila et al. 2006; Hisashi et al. 2008).

Taken together, in vitro and in vivo data convincingly point to the existence of a vigorous antixenograft T-cell immune response. Still, many investigators in the field share the impression that, with current immunosuppression, this cell-mediated immune response is less destructive than the response induced by activation of the humoral immune system, although the contribution of the $\mathrm{T}$ cells in the elicited antibody production should not be underestimated. 
It is in the setting of nonvascularized xenografts such as porcine pancreatic islet xenotransplantation that $\mathrm{T}$ cells have been found to play the most significant part. Early studies on mice showed that fetal pig islets transplanted under the kidney capsule were rapidly rejected in normal but not in athymic (Karlsson-Parra et al. 1996) or TCR-deficient mice (Benda et al. 1998). The $T$ cells infiltrating the graft were mainly $\mathrm{CD}^{+}{ }^{+}$cells, and no $\mathrm{CD} 8^{+}$cells were detected. These studies also suggested that the xenogeneic islet rejection was a T-cell-dependent process, possibly via the stimulation of the effector activity of macrophages (Karlsson-Parra et al. 1996).

Returning to the clinically most relevant pig-to-primate models, porcine islets infused through the portal vein were lost en masse immediately after coming into contact with primate blood (Bennet et al. 2000) owing to the so-called instant blood-mediated inflammatory reaction (IBMIR), which is characterized by macroscopic coagulation, rapid platelet consumption, leukocyte infiltration, and the deposition of complement components (Goto et al. 2008; van der Windt et al. 2009). It has also been shown that islets from neonatal (Cardona et al. 2006) or adult pigs (Kirchhof et al. 2004) infused intraportally in nonimmunosuppressed primates and engrafted in the liver are destroyed within 3-5 d with a marked infiltration of $\mathrm{CD}^{+}$and $\mathrm{CD}^{+}$cells and macrophages (Kirchhof et al. 2004; Cardona et al. 2006).

When immunosuppressive therapy comprising basiliximab, FTY720, everolimus, and anti-CD154 was administered, adult islet survival was prolonged to up to $187 \mathrm{~d}$ (Hering et al. 2006). Despite the absence of any IgM or IgG and complement deposition, peri-/intragraft T-cell infiltration, both $\mathrm{CD} 4^{+}$and $\mathrm{CD} 8^{+}$, and macrophages were apparent in the rejected grafts. The high levels of circulating indirectly activated donor-reactive $\mathrm{T}$ cells in rejecting recipients suggest a crucial role of such infiltrating cells in islet rejection, and their incomplete inhibition may have been the primary cause of graft rejection (Hering et al. 2006; Hering and Walawalkar 2009).

\section{The Role of the Cells Involved in the Innate Immune Response}

At least three types of cell-namely, neutrophils, natural killer (NK) cells, and macrophages-should be critically considered when analyzing the potential contribution to xenograft rejection of the cellular component of the innate immune system. For each of these, recruitment, adhesion, and trans-endothelial migration are mediated by different receptor-ligand interactions and finely regulated by chemotactic cytokines and chemokines released by host cells and the activated endothelium following xenotransplantation (Holgersson et al. 2002). Compatibility between human receptors and their porcine counterparts is therefore indispensable for the optimal migration and function of each of these cells.

Human naïve neutrophils have been found capable of directly recognizing and binding naïve xenogeneic endothelial cells more avidly than their allogeneic counterpart, irrespective of any presence of $\alpha \mathrm{Gal}$, ICAM-1 (Sheikh et al. 2002), xenogeneic natural antibodies, or complement (Al-Mohanna et al. 1997; Cardozo et al. 2004). On the other hand, complement has been seen to increase neutrophil adhesion (Vercellotti et al. 1991). Human neutrophils activate porcine but not allogeneic endothelial cells (as shown by an increased P-selectin and VCAM-1 expression), making porcine endothelium more prone to human NK-driven cytotoxicity. In turn, porcine endothelium secretes an as-yet-unidentified soluble factor that is chemotactic for human neutrophils (Cardozo et al. 2004). The xenogeneic cell contact with porcine endothelial cell induces human neutrophil activation with an increased output of toxic reactive oxygen metabolites (ROM), irrespective of any presence of $\alpha \mathrm{Gal}$ epitopes, natural xenoantibodies, or complement (Al-Mohanna et al. 2005). Xenogeneic activation also prompts neutrophils to secrete proinflammatory cytokines, such as IL- $1 \alpha / \beta$, IL- 6 , and IL- 8 , involved in cellular and humoral adaptive immune responses and platelet activation, crucial players in the rejection process. As shown in some studies, polymorphonuclear neutrophils appear to 
be the first line of cells infiltrating and possibly damaging (van der Windt et al. 2007) cell and solid-organ xenografts soon after transplantation (Kirchhof et al. 2004; Hisashi et al. 2008; Ezzelarab et al. 2009; Shimizu et al. 2012). As shown in the majority of reports, however, this infiltration appears to be replaced by $\mathrm{T}$ cells and macrophages (Kirchhof et al. 2004; Hisashi et al. 2008; Ezzelarab et al. 2009; Shimizu et al. 2012). Although in vitro studies suggest that neutrophils have the potential to damage porcine cells and tissues, there is only limited evidence of their detrimental role in vivo beyond HAR.

Other important players in the antixenograft innate immune response are the NK cells, a subset of lymphocytes capable of killing cells recognized as non-self, including tumor cells and virus-infected cells. Several lines of research have suggested that, following adhesion to porcine grafts, NK cells may have a detrimental role in pig-to-primate xenotransplantation. First, it has been shown in vitro that porcine cells are susceptible to direct cell-mediated damage and to ADCC mediated by naïve or activated human NK cells (Horvath-Arcidiacono et al. 2006; Schneider and Seebach 2008; Kennett et al. 2010; Sommaggio et al. 2012). The direct cytotoxic activity of NK cells, which is inhibited primarily by human MHC class I molecules through inhibitory NK receptors, is not blocked by SLA class I products. Ligands on porcine cells, one of which has recently been identified (Lilienfeld et al. 2006), can interact efficiently with the activating receptors NKp44 or NKG2D, resulting in direct human NK cell cytotoxicity (Forte et al. 2005). Interaction between the porcine costimulatory molecule CD86 and a variant form of CD28 on hNK cells may also be involved in direct NK cytotoxicity (Costa et al. 2002), whereas the expression of $\alpha \mathrm{Gal}$ residues on pig endothelium does not appear to have a major role, because the use of cells lacking $\alpha$ Gal expression did not prevent direct NK-mediated cell lysis (Baumann et al. 2004; Horvath-Arcidiacono et al. 2006). Second, it has also been shown that, on activation by porcine endothelial cells, NK cells produce INF- $\gamma$, ultimately potentiating T-cell activity (Xu et al. 2002). Third, NK cells rapidly infiltrate porcine xenografts perfused ex vivo with human blood (Kirk et al. 1993; Inverardi and Pardi 1994). In explanted xenografts, on the other hand, NK cells were found in small numbers (Davila et al. 2006; Hisashi et al. 2008; Shimizu et al. 2012) or were not reported (Ashton-Chess et al. 2003; Cozzi et al. 2003; McGregor et al. 2005; Ezzelarab et al. 2009), except for one case in which the particular features of the model may have heavily influenced the outcome (Itescu et al. 1998). It is worth noting, however, that the in vivo studies conducted to date cannot definitely rule out the possibility of NK cells being directly implicated in the untimely failure of xenografts.

Monocytes and differentiated macrophages are the third component of the innate immune system considered here. These phagocytic cells' involvement in xenograft rejection has been amply discussed, especially in islet xenotransplantation, although the reported degree and timing of infiltration have varied in the different models. After xenotransplantation, monocytes attracted by graft proinflammatory mediators migrate into the xenograft and infiltrate it by virtue of the cross-species interaction of adhesion molecules, including CD49d/CD29 and $\beta_{2}$-integrins (Hauzenberger et al. 2000; Schneider et al. 2009). Macrophage recruitment appears to be more intensive when xenogeneic rather than allogeneic cells are transplanted (Fox et al. 2001), and it seems to be T-cell independent. The role of $\alpha \mathrm{Gal}$ in increasing monocyte adhesion is still being debated because macrophage infiltration has been identified in adult porcine islet grafts known to express low levels of $\alpha \mathrm{Gal}$ epitopes, and in islets from GalT-KO donors (Thompson et al. 2011a). In xenotransplantation, macrophages exert their phagocytic action and modulate adaptive immunity by contributing to cell recruiting and antigen presentation. Upon contact with xenogeneic cells, macrophages have been seen to allow the recruitment of both $\mathrm{CD} 4^{+}$and $\mathrm{CD} 8^{+}$ $\mathrm{T}$ cells. In turn, optimal macrophage activation requires a contribution from the $\mathrm{CD} 4^{+} \mathrm{T}$ cells, possibly via the INF- $\gamma$ pathway (Yi et al. 2002), ultimately resulting in graft rejection (Fox et al. 2001; Yi et al. 2003). 
Xenotransplantation Immunology

The macrophages' phagocytic activity is mediated by an ADCC mechanism or direct cell-to-cell contact (Jackson and Evans 2000). Like the case of NK cells, the "missing self" (Ljunggren and Karre 1990) has been suggested as the regulatory mechanism behind their phagocytic activity against xenografts. It has been shown, in fact, that the lack of any functional interaction between porcine CD47 (a membrane glycoprotein expressed ubiquitously on the cell surface of xenografts) with the human species-specific macrophage inhibitory receptor SIRP $\alpha$ makes porcine cells more susceptible to macrophage-mediated damage (Ide et al. 2007).

Macrophages activated by $\mathrm{CD} 4^{+} \mathrm{T}$ cells have an important role in the destruction of pancreatic islet xenografts. In rodents, macrophages are reportedly the earliest infiltrating cell population after islet transplantation under the kidney capsule (Wallgren et al. 1995). Macrophages activated by $\mathrm{CD} 4{ }^{+} \mathrm{T}$ cells in islet-transplanted NOD-SCID have also been found to cause graft destruction within $8 \mathrm{~d}$ (Yi et al. 2003). After intraportal islet injection in nonhuman primates, $\mathrm{T}$ cells reportedly preceded the influx of macrophages (Kirchhof et al. 2004) into the graft. Together with T cells, macrophages might contribute to islet damage (Kirchhof et al. 2004; Cardona et al. 2006; Hering et al. 2006). They appear to have a pivotal role in cellular graft rejection, and they have also been identified soon after solid organ xenografting. They continue to be detectable up until the graft is rejected (Ashton-Chess et al. 2003; Cozzi et al. 2003; Hisashi et al. 2008; Ezzelarab et al. 2009; Shimizu et al. 2012), and they have been accused of contributing to the onset of graft failure and TM (Ezzelarab et al. 2009).

\section{IMMUNE STRATEGIES TO EXTEND XENOGRAFT SURVIVAL}

\section{Preventing Humoral Rejection}

Several strategies may be envisaged to deal with the detrimental role of the humoral antixenograft immune response, as briefly reviewed below.

\section{Removing the Key Target Antigens}

Removing the immunogenic epitopes recognized by preexisting or elicited antixenograft antibodies is an obvious approach that has been pursued successfully in the case of the $\alpha \mathrm{Gal}$ epitope (Dai et al. 2002; Lai et al. 2002; Phelps et al. 2003). The technology is available for preventing the expression of undesirable target antigens on pig cells (Hauschild et al. 2011).

At least two caveats should be borne in mind, however, when using such an approach. First, the number of epitopes potentially eliciting a humoral response to a xenograft is considerable, in theory at least (Burlak et al. 2012), making it unrealistic to try and delete them all. Second, deleting epitopes may sometimes result in an unpredictable de novo appearance of new target molecules that are recognized as foreign (Diswall et al. 2010). Therefore, apart from a handful of antigens (e.g., the $\alpha \mathrm{Gal}$ and possibly also the Neu5GC epitopes [Lutz et al. 2013], and a few others) whose deletion is considered crucial to help establish an advantageous immunological context, such as accommodation or tolerance, the application of this approach in xenotransplantation is probably of limited value.

\section{Preventing the Activation of the Complement Cascade Triggered by Xenoreactive Antibodies}

Several efforts have been made to eliminate the detrimental effect of the complement cascade's activation on the xenograft, including the use of specific soluble complement inhibitors, such as soluble complement receptor type 1 (Lam et al. 2005), or the cobra venom factor (Kobayashi et al. 1997), and the production of animals transgenic for human complement regulatory proteins (CRP), such as hCD55, hCD46, or hCD59 (Fodor et al. 1994; Cozzi and White 1995; McCurry et al. 1995; Cowan et al. 2000; Loveland et al. 2004; Menoret et al. 2004). This approach represents an elegant strategy for down-regulating local complement activation on the xenograft while preserving systemic complement activity as a first line of defense. The expression of hCRP by the xenograft cell sur- 
face may have a beneficial role on T-cell immunity too because molecules such as hCD55 can negatively modulate T-cell expansion and function (Heeger et al. 2005; Kwan et al. 2012). Judging from the data obtained so far, however, pig xenografts expressing CRPs are not protected from the overwhelming complement activation occurring in AHXR, even if CRPs are expressed on a GalT-KO background. This underlines the existing limitation of the use of CRP transgenic organs (Le Bas-Bernardet et al. 2011; Tazelaar et al. 2011). Indeed, it may be necessary to implement a multistep inhibition of the complement cascade, associated with a tight regulation of the coagulation system involved in complement activation (Huber-Lang et al. 2006).

\section{Removing Xenoreactive Antibodies or Cells Producing Xenoreactive Antibodies}

Removing or neutralizing xenoreactive antibodies with the aid of antigen-specific immunoadsorbants (Katopodis et al. 2002; Brandl et al. 2007), ex vivo organ perfusion, or nonspecific tools such as Sepharose beads conjugated with polyclonal antibodies against human Ig (Brenner et al. 2005) may help to protect grafts, at least temporarily, from offending antibodies. Strategies have also been attempted to delete antibody-producing cells using aspecific pharmacological immunosuppression (e.g., with cyclophosphamide) (Cozzi et al. 2000, 2003) or specifically targeting the B-cell lineage with anti-CD20 monoclonal antibodies (Vugmeyster et al. 2005; Mohiuddin et al. 2012), with ricin A-labeled target molecules (Tanemura et al. 2002), or even using the proteasome inhibitor bortezomib (Bauer et al. 2010). To date, however, findings indicate that none of these strategies is yet able to prolong xenograft survival indefinitely, suggesting that these approaches need to be further refined.

\section{Inducing Accommodation and B-Cell Tolerance}

Inducing accommodation-defined as longterm graft survival notwithstanding the contin- uing presence of xenoreactive antibodies and complement (Bach et al. 1991) — is a very appealing option for preventing antibody-mediated damage. Certain changes in the graft, such as the up-regulation of protective genes or changes in the antigens targeted by the humoral response after transplantation, may at least partially explain the mechanisms behind accommodation (Koch et al. 2004). Alternatively, changes in the recipient's antibody repertoire may underlie this fortunate situation. Be that as it may, accommodation is currently seen as a phenomenon requiring further investigation to better identify its potential in the primate xenotransplantation setting.

The induction of B-cell tolerance against xenogeneic antigens is another very attractive idea for preventing antibody-mediated damage. Inducing chimerism in the recipient has been considered indispensable to achieving tolerance. Elegant preliminary studies conducted in mice to induce a tolerance of B-cell clones producing anti- $\alpha \mathrm{Gal}$ antibodies have convincingly shown that inducing a mixed hematopoietic chimerism may lead to B-cell tolerance. This mixed hematopoietic chimerism was obtained by infusing allogeneic (Ohdan et al. 1999) $\alpha \mathrm{Gal}^{+}$T-cell-depleted bone marrow into $\alpha \mathrm{Gal}^{-}$mice submitted to lethal whole-body irradiation (Yang et al. 1998) or to a nonmyeloablative regimen (Ohdan et al. 1999). The resulting chimerism was associated with an indefinite acceptance of $\alpha \mathrm{Gal}^{+}$grafts with no need for further immunosuppression (Ohdan et al. 1999). Tolerance early after transplantation was induced by anergy, requiring the persistence of $\alpha \mathrm{Gal}^{+}$cells, whereas clonal deletion or receptor editing was believed to be the mechanism involved in B-cell tolerization at subsequent stages (Kawahara et al. 2005). B-cell tolerance has also been achieved in relation to non- $\alpha$ Gal epitopes (Aksentijevich et al. 1992). Using a microchimerism-based approach, Griesemer and colleagues recently succeeded in obtaining a specific humoral unresponsiveness to swine antigens in baboons. This is a promising strategy and its refinement may, at some stage, enable long-term xenograft acceptance in primates (Tseng et al. 2004; Griesemer et al. 2010). 


\section{Preventing Cell-Mediated Rejection}

Several strategies have also been developed to block innate and adaptive cell-mediated xenograft rejection.

\section{Systemic Immunosuppression}

Many immunosuppressive approaches have been attempted to improve xenograft survival, including conventional and also more recently developed molecules or biologics. The introduction of anti-CD154 monoclonal antibodies has contributed to a significantly longer solidorgan and islet xenograft survival (Kuwaki et al. 2005; Yamada et al. 2005; Cardona et al. 2006; Hering et al. 2006), while preventing elicited antibody responses (Ezzelarab et al. 2012). These results have been severely penalized by thromboembolic events that have precluded further use of anti-CD154 antibodies and prompted researchers to explore other therapeutic options, such as anti-CD40 agents or CTLA4Ig-based strategies in combination with immunosuppressive drugs (Ezzelarab et al. 2009; Thompson et al. 2011b). Using an anti-CD40 antibody associated with belatacept extended neonatal porcine islet survival (Thompson et al. 2011b), although further studies are needed to confirm this finding. On the other hand, Ezzelarab et al. (2012) found in an artery-patch xenotransplantation model that CTLA-4Ig therapy was probably not as efficacious as CD154/ CD40 inhibitors in preventing cellular and humoral response (Dons et al. 2012).

\section{Local Immunosuppression Using Specifically Engineered Source Animals}

Genetic engineering of the xenograft has also been proposed as a means to inhibit rejection locally, while containing systemic immunosuppression and its side effects. Several approaches have been considered, and novel pig lines expressing molecules that may block the recipient's immune cells have been produced.

When a mutant form of the CIITA gene (an essential coactivator for the transcription of MHC class II genes) was introduced on a
GalT-KO/CD46/CD55 background, SLA II molecules were down-regulated and $\mathrm{CD}_{4}^{+}$ T-cell proliferation was inhibited in MLR studies (Ayares et al. 2011). Several porcine and human CTLA-4Ig transgenic animals were obtained (Martin et al. 2005; Phelps et al. 2009; Koshika et al. 2011), and hCTLA-4Ig transgenic pigs expressing the transgene selectively in neurons enabled a long-term survival of neural precursors in mice (Martin et al. 2005) and primates (Aron Badin et al. 2009). Because the constitutive expression of pCTLA-4Ig resulted in severely immunosuppressed animals, pigs with an inducible pCTLA-4Ig expression have recently been obtained (Klymiuk et al. 2012). As for the NK cells, transgenic pigs expressing HLA-E (a molecule inhibiting NK cell adhesion and cytotoxicity) have also been produced (Weiss et al. 2009). Transgenic pigs expressing human CD47 have likewise recently been generated (Tena et al. 2011). Although the potential of these genetic modifications still remains to be tested in vivo, their association with other strategies may lead to a better graft survival.

\section{Using Mechanical Barriers}

Encapsulating xenogeneic islets has been suggested as a strategy to prevent cell-mediated rejection and enable graft survival in the absence of immunosuppression. The crucial issues to tackle in this area include the biocompatibility of the encapsulating material, the mechanical stability of the capsules, and the selection of the implantation site (Dufrane et al. 2006b). Microencapsulation of pig islets in water-soluble polymers, such as alginate (Dufrane et al. 2006a), or macroencapsulation in subcutaneous devices permeable to glucose, insulin, and nutrients (but not to antibodies or the immune system's cellular components) have enabled islets to survive in primates for up to 6 mo without any immunosuppression (Dufrane et al. 2010). These findings suggest that, notwithstanding the currently limited life span of such devices, refining this approach may lead in the future to the successful clinical application of islet xenotransplantation. 
M. Vadori and E. Cozzi

\section{T-Cell Tolerance and Tregsv}

The feasibility of inducing T-cell tolerance has also been explored. Early studies on T-cell tolerance in mice showed that transplanting fetal or neonatal pig thymic tissue into thymectomized mice could induce a central tolerance of pig skin grafts (Zhao et al. 1996). This strategy was successfully applied to the transplantation of GalT-KO pig kidneys into baboons, resulting in a normal renal function for up to $83 \mathrm{~d}$ (Yamada et al. 2005; Griesemer et al. 2009). This result was achieved by transplanting thymic tissue under the donor renal capsule (thymokidney) in recipients exposed to a protocol that included thymectomy, splenectomy, T-cell depletion, and whole-body irradiation. Doing without whole-body irradiation enabled a mean survival of more than $50 \mathrm{~d}$. Thymic grafts supported thymopoiesis, and there was evidence of $\mathrm{CD}^{+}{ }^{+} \mathrm{CD} 3^{-}$baboon cells adjacent to porcine thymic epithelial cells (Griesemer et al. 2009). Donor-specific unresponsiveness with respect to the normal responses to allogeneic third parties was also detected in CTL assays. As an alternative approach to enabling T-cell tolerance in xenotransplantation, thymic lobe (vascularized thymic lobe, VTL) transplantation from either $\alpha \mathrm{Gal}^{+}$(Yamamoto et al. 2005) or GalT-KO donors (Yamada et al. 2005) has also been proposed. This procedure enabled early thymopoiesis, reconstitution of the recipient's naïve T-cell population, and donor-specific unresponsiveness, albeit for a limited time (Yamamoto et al. 2005). These regimens to induce T-cell tolerance clearly require further fine-tuning, but the results achieved to date suggest that this approach may soon become a viable option for primates.

Inducing tolerance through regulatory $\mathrm{T}$ cell-based therapies also has its appeal for both allo- and xenotransplantation. Regulatory $\mathrm{T}$ cells have been found to suppress T-cell-direct (Wu et al. 2008) and -indirect xenogeneic responses to T cells (Nishimura et al. 2010), B cells (Singh et al. 2012), macrophage activation (Fu et al. 2008), and-antigen-presenting cell functions (Cederbom et al. 2000; Fu et al. 2008). Several types of regulatory $\mathrm{T}$ cells (Tregs) have been described, and those naturally occurring in the immune system (nTregs) account for nearly $3 \%-10 \%$ of the peripheral CD $4^{+} \mathrm{T}$ cells (Dons et al. 2010; Muller et al. 2011). Phenotypically, nTregs are characterized by the constitutive presence of CD4, CD25, the IL-2 receptor $\alpha$ chain, and the intracellular expression of transcription factor Forkhead box P3 (Foxp3), and by little or no expression of CD127, the IL-2 receptor $\alpha$-chain. The suppressor activity of nTregs depends on cell-to-cell contact via important costimulatory molecules, which include CTLA- 4 , membrane-bound TGF- $\beta$ latency-associated peptide (LAP), soluble inducible costimulatory molecule (ICOS), galectin-1, CD39, CD73, and PD-1, or it is mediated by regulatory cytokines such as IL-10, TGF- $\beta$, or IL-35 (Muller et al. 2011, 2012). Notably, the expression of hPD-L1 (the ligand of activated $\mathrm{T}$ cells PD-1) by porcine endothelial cells stimulates the proliferation of human Foxp $3^{+} \mathrm{CD} 4^{+}$ $\mathrm{T}$ cells both in vitro and in vivo, inducing the expression of CD73 by Tregs and promoting the production of IL-10, and reducing the proinflammatory Th1 and Th17 cytokines. The in vivo infusion of hPD- $\mathrm{L}^{+}$endothelial cells prolongs the survival of porcine skin grafts, favoring the expansion of Foxp $3^{+} \mathrm{CD} 4^{+} \mathrm{T}$ cells (Ding et al. 2011). Much the same results have been obtained in mice by grafting porcine endothelial cells transfected with ICOS-Ig, a soluble form of ICOS (Hodgson et al. 2011), suggesting that Treg-based strategies may represent a novel path toward achieving tolerance in xenotransplantation.

\section{CONCLUSIONS}

To sum up, despite the challenges that remain, the potential health benefits afforded by xenotransplantation make it a fascinating area of research that deserves to be pursued. Important preclinical data have been generated in recent years, making the initiation of clinical trials a realistic option for the not-too-distant future. At this point, many researchers in this field would agree that genetic engineering of the donor species may be needed to improve current results. Such genetic engineering should selec- 
tively address only major interspecies molecular discrepancies, like those involved in regulating the complement or coagulation cascades, eliminate highly immunogenic epitopes, or block major immune cell activation pathways. This should ultimately contribute to the development of the ideal milieu in which novel immunosuppressive drugs or innovative strategies designed to enable accommodation or tolerance will have the greatest chances of success in terms of achieving long-term xenograft survival. It has also become clear that, before xenotransplantation can enter the clinical arena, a multidisciplinary approach will be needed to comprehensively tackle the various issues relating to the use of xenografts to cure human diseases. The safety-related, ethical, and regulatory issues of xenotransplantation (which were not the object of this review) are already being addressed by highly specialized and dedicated investigators, and the multidisciplinary effort currently under way is expected to enable xenotransplantation to happen with a favorable risk/benefit ratio in the foreseeable future.

\section{REFERENCES}

Aksentijevich I, Sachs DH, Sykes M. 1992. Humoral tolerance in xenogeneic BMTrecipients conditioned by a nonmyeloablative regimen. Transplantation 53: 1108-1114.

Al-Mohanna F, Collison K, Parhar R, Kwaasi A, Meyer B, Saleh S, Allen S, al-Sedairy S, Stern D, Yacoub M. 1997. Activation of naive xenogeneic but not allogeneic endothelial cells by human naive neutrophils: A potential occult barrier to xenotransplantation. Am J Pathol 151: $111-120$.

Al-Mohanna F, Saleh S, Parhar RS, Khabar K, Collison K. 2005. Human neutrophil gene expression profiling following xenogeneic encounter with porcine aortic endothelial cells: The occult role of neutrophils in xenograft rejection revealed. J Leukoc Biol 78: 51-61.

Aron Badin R, Padoan A, Vadori M, Boldrin M, Cavicchioli L, De Benedictis G, Fante F, Seveso M, Sgarabotto D, Jan C, et al. 2009. Transgenic porcine embryonic xenografts as a treatment for Parkinson's disease in non-human primates. Xenotrasplantation 16: 543 .

Ashton-Chess J, Roussel JC, Manez R, Ruiz C, Moreau A, Cozzi E, Minault D, Soulillou JP, Blancho G. 2003. Cellular participation in delayed xenograft rejection of hCD55 transgenic pig hearts by baboons. Xenotransplantation 10: $446-453$.

Ayares D, Phelps C, Vaught T, Ball S, Mendicino M, Ramsoondar J, Monahan J, Delong A, Walters A, Starzl T, et al. 2011. Multitrasgenic pigs for vascularized organ xenografts. Xenotransplantation 18: 269.
Bach FH, Turman MA, Vercellotti GM, Platt JL, Dalmasso AP. 1991. Accommodation: A working paradigm for progressing toward clinical discordant xenografting. Transplant Proc 23: 205-207.

Basnet NB, Ide K, Tahara H, Tanaka Y, Ohdan H. 2010. Deficiency of $\mathrm{N}$-glycolylneuraminic acid and Gal $\alpha 1-$ 3Galß1-4GlcNAc epitopes in xenogeneic cells attenuates cytotoxicity of human natural antibodies. Xenotransplantation 17: 440-448.

Bauer A, Postrach J, Thormann M, Blanck S, Faber C, Wintersperger B, Michel S, Abicht JM, Christ F, Schmitz C, et al. 2010. First experience with heterotopic thoracic pigto-baboon cardiac xenotransplantation. Xenotransplantation 17: 243-249.

Baumann BC, Forte P, Hawley RJ, Rieben R, Schneider MK, Seebach JD. 2004. Lack of galactose- $\alpha$-1,3-galactose expression on porcine endothelial cells prevents complement-induced lysis but not direct xenogeneic NK cytotoxicity. J Immunol 172: 6460-6467.

Baumann BC, Stussi G, Huggel K, Rieben R, Seebach JD. 2007. Reactivity of human natural antibodies to endothelial cells from Gal $\alpha(1,3) \mathrm{Gal}$-deficient pigs. Transplantation 83: 193-201.

Benda B, Sandberg JO, Holstad M, Korsgren O. 1998. T cells in islet-like cell cluster xenograft rejection: A study in the pig-to-mouse model. Transplantation 66: 435-440.

Bennet W, Groth CG, Larsson R, Nilsson B, Korsgren O. 2000. Isolated human islets trigger an instant blood mediated inflammatory reaction: Implications for intraportal islet transplantation as a treatment for patients with type 1 diabetes. Ups J Med Sci 105: 125-133.

Blixt O, Kumagai-Braesch M, Tibellb A, Groth C, Holgerssonc J. 2009. Anticarbohydrate antibody repertoires in patients transplanted with fetal pig islets revealed by glycan arrays. Am J Transplant 9: 83-90.

Brandl U, Erhardt M, Michel S, Jockle H, Burdorf L, Bittmann I, Rossle M, Mordstein V, Brenner P, Hammer C, et al. 2007. Soluble Gal $\alpha(1,3) \mathrm{Gal}$ conjugate combined with hDAF preserves morphology and improves function of cardiac xenografts. Xenotransplantation 14: 323-332.

Breimer ME. 2011. Gal/non-Gal antigens in pig tissues and human non-Gal antibodies in the GalT-KO era. Xenotransplantation 18: 215-228.

Brenner P, Schmoeckel M, Wimmer C, Rucker A, Eder V, Uchita S, Brandl U, Hinz M, Felbinger T, Meiser B, et al 2005. Combination of hDAF-transgenic pig hearts and immunoadsorption in heterotopic xenotransplantation of immunosuppressed baboons. Transplant Proc 37: $483-486$.

Buhler L, Awwad M, Basker M, Gojo S, Watts A, Treter S, Nash K, Oravec G, Chang Q, Thall A, et al. 2000. Highdose porcine hematopoietic cell transplantation combined with CD40 ligand blockade in baboons prevents an induced anti-pig humoral response. Transplantation 69: $2296-2304$.

Bulato C, Radu C, Simioni P. 2012. Studies on coagulation incompatibilities for xenotransplantation. Methods $\mathrm{Mol}$ Biol 885: 71-89.

Burlak C, Wang ZY, Chihara RK, Lutz AJ, Wang Y, Estrada JL, Tector AJ. 2012. Identification of human preformed antibody targets in GTKO pigs. Xenotransplantation 19: 92-101. 
M. Vadori and E. Cozzi

Byrne GW, Stalboerger PG, Davila E, Heppelmann CJ, Gaz MH, McGregor HC, LaBreche PT, Davies WR, Rao VP, Oi K, et al. 2008. Proteomic identification of non-Gal antibody targets after pig-to-primate cardiac xenotransplantation. Xenotransplantation 15: 268-276.

Byrne GW, Stalboerger PG, Du Z, Davis TR, McGregor CG. 2011. Identification of new carbohydrate and membrane protein antigens in cardiac xenotransplantation. Transplantation 91: 287-292.

Cardona K, Korbutt GS, Milas Z, Lyon J, Cano J, Jiang W, Bello-Laborn H, Hacquoil B, Strobert E, Gangappa S, et al. 2006. Long-term survival of neonatal porcine islets in nonhuman primates by targeting costimulation pathways. Nat Med 12: 304-306.

Cardozo LA, Rouw DB, Ambrose LR, Midulla M, Florey O, Haskard DO, Warrens AN. 2004. The neutrophil: The unnoticed threat in xenotransplantation? Transplantation 78: $1721-1728$.

Cederbom L, Hall H, Ivars F. 2000. CD $4^{+} \mathrm{CD} 25^{+}$regulatory $\mathrm{T}$ cells down-regulate co-stimulatory molecules on antigen-presenting cells. Eur J Immunol 30: 1538-1543.

Chen G, Qian H, Starzl T, Sun H, Garcia B, Wang X, Wise Y, Liu Y, Xiang Y, Copeman L, et al. 2005. Acute rejection is associated with antibodies to non-Gal antigens in baboons using Gal-knockout pig kidneys. Nat Med 11: 1295-1298.

Chen G, Sun H, Yang H, Kubelik D, Garcia B, Luo Y, Xiang Y, Qian A, Copeman L, Liu W, et al. 2006. The role of antinon-Gal antibodies in the development of acute humoral xenograft rejection of hDAF transgenic porcine kidneys in baboons receiving anti-Gal antibody neutralization therapy. Transplantation 81: 273-283.

Choo JK, Seebach JD, Nickeleit V, Shimizu A, Lei H, Sachs DH, Madsen JC. 1997. Species differences in the expression of major histocompatibility complex class II antigens on coronary artery endothelium: Implications for cell-mediated xenoreactivity. Transplantation 64: 13151322

Costa C, Barber DF, Fodor WL. 2002. Human NK cell-mediated cytotoxicity triggered by CD 86 and Gal $\alpha 1,3-$ Gal is inhibited in genetically modified porcine cells. J Immunol 168: 3808-3816.

Cowan PJ, Aminian A, Barlow H, Brown AA, Chen CG, Fisicaro N, Francis DM, Goodman DJ, Han W, Kurek M, et al. 2000. Renal xenografts from triple-transgenic pigs are not hyperacutely rejected but cause coagulopathy in non-immunosuppressed baboons. Transplantation 69: 2504-2515.

Cowan PJ, Robson SC, d'Apice AJ. 2011. Controlling coagulation dysregulation in xenotransplantation. Curr Opin Organ Transplant 16: 214-221.

Cozzi E, White DJ. 1995. The generation of transgenic pigs as potential organ donors for humans. Nat Med 1: $964-$ 966.

Cozzi E, Bhatti F, Schmoeckel M, Chavez G, Smith KG, Zaidi A, Bradley JR, Thiru S, Goddard M, Vial C, et al. 2000. Long-term survival of nonhuman primates receiving lifesupporting transgenic porcine kidney xenografts. Transplantation 70: 15-21.

Cozzi E, Vial C, Ostlie D, Farah B, Chavez G, Smith KG, Bradley JR, Thiru S, Davies HF, Wallwork J, et al. 2003. Maintenance triple immunosuppression with cyclospor- in $\mathrm{A}$, mycophenolate sodium and steroids allows prolonged survival of primate recipients of hDAF porcine renal xenografts. Xenotransplantation 10: 300-310.

Cretin N, Bracy J, Hanson K, Iacomini J. 2002. The role of T cell help in the production of antibodies specific for Gal $\alpha 1-3 G a l . J$ Immunol 168: 1479-1483.

Crikis S, Cowan PJ, d'Apice AJ. 2006. Intravascular thrombosis in discordant xenotransplantation. Transplantation 82: 1119-1123.

Dai Y, Vaught TD, Boone J, Chen SH, Phelps CJ, Ball S, Monahan JA, Jobst PM, McCreath KJ, Lamborn AE, et al. 2002. Targeted disruption of the $\alpha 1,3$-galactosyltransferase gene in cloned pigs. Nat Biotechnol 20: 251255.

Davila E, Byrne GW, LaBreche PT, McGregor HC, Schwab AK, Davies WR, Rao VP, Oi K, Tazelaar HD, Logan JS, et al. 2006. T-cell responses during pig-to-primate xenotransplantation. Xenotransplantation 13: 31-40.

Diaz Varela I, Sanchez Mozo P, Centeno Cortes A, Alonso Blanco C, Valdes Canedo F. 2003. Cross-reactivity between swine leukocyte antigen and human anti-HLAspecific antibodies in sensitized patients awaiting renal transplantation. J Am Soc Nephrol 14: 2677-2683.

Ding Q, Lu L, Zhou X, Zhou Y, Chou KY. 2011. Human PD-L1-overexpressing porcine vascular endothelial cells induce functionally suppressive human $\mathrm{CD} 4^{+}$ CD25hiFoxp3 ${ }^{+}$Treg cells. J Leukoc Biol 90: 77-86.

Diswall M, Angstrom J, Karlsson H, Phelps CJ, Ayares D, Teneberg S, Breimer ME. 2010. Structural characterization of $\alpha 1,3$-galactosyltransferase knockout pig heart and kidney glycolipids and their reactivity with human and baboon antibodies. Xenotransplantation 17: 48-60.

Diswall M, Gustafsson A, Holgersson J, Sandrin MA, Breimer ME. 2011. Antigen-binding specificity of anti$\alpha \mathrm{Gal}$ reagents determined by solid-phase glycolipidbinding assays. A complete lack of $\alpha \mathrm{Gal}$ glycolipid reactivity in $\alpha 1,3 \mathrm{GalT}-\mathrm{KO}$ pig small intestine. Xenotransplantation 18: $28-39$.

Dons EM, Raimondi G, Cooper DK, Thomson AW. 2010. Non-human primate regulatory T cells: Current biology and implications for transplantation. Transplantation 90: 811-816.

Dons EM, Montoya C, Long CE, Hara H, Echeverri GJ, Ekser B, Ezzelarab C, Medellin DR, van der Windt DJ, Murase N, et al. 2012. T-cell-based immunosuppressive therapy inhibits the development of natural antibodies in infant baboons. Transplantation 93: 769-776.

Dorling A, Lechler RI. 1998. T cell-mediated xenograft rejection: Specific tolerance is probably required for long term xenograft survival. Xenotransplantation 5: 234-245.

Dorling A, Lombardi G, Binns R, Lechler RI. 1996. Detection of primary direct and indirect human anti-porcine $\mathrm{T}$ cell responses using a porcine dendritic cell population. Eur J Immunol 26: 1378-1387.

Dufrane D, Goebbels RM, Saliez A, Guiot Y, Gianello P. 2006a. Six-month survival of microencapsulated pig islets and alginate biocompatibility in primates: Proof of concept. Transplantation 81: 1345-1353.

Dufrane D, Steenberghe M, Goebbels RM, Saliez A, Guiot Y, Gianello P. 2006b. The influence of implantation site on the biocompatibility and survival of alginate encapsulated pig islets in rats. Biomaterials 27: 3201-3208. 
Dufrane D, Goebbels RM, Gianello P. 2010. Alginate macroencapsulation of pig islets allows correction of streptozotocin-induced diabetes in primates up to 6 months without immunosuppression. Transplantation 90: $1054-$ 1062.

Ezzelarab M, Garcia B, Azimzadeh A, Sun H, Lin CC, Hara H, Kelishadi S, Zhang T, Lin YJ, Tai HC, et al. 2009. The innate immune response and activation of coagulation in $\alpha 1,3$-galactosyltransferase gene-knockout xenograft recipients. Transplantation 87: 805-812.

Ezzelarab MB, Ekser B, Echeverri G, Hara H, Ezzelarab C, Long C, Bajona P, Garcia B, Murase N, Ayares D, et al. 2012. Costimulation blockade in pig artery patch xenotransplantation-A simple model to monitor the adaptive immune response in nonhuman primates. Xenotransplantation 19: 221-232.

Fang J, Walters A, Hara H, Long C, Yeh P, Ayares D, Cooper DK, Bianchi J. 2012. Anti-gal antibodies in $\alpha 1,3$-galactosyltransferase gene-knockout pigs. Xenotransplantation 19: $305-310$.

Fodor WL, Williams BL, Matis LA, Madri JA, Rollins SA, Knight JW, Velander W, Squinto SP. 1994. Expression of a functional human complement inhibitor in a transgenic pig as a model for the prevention of xenogeneic hyperacute organ rejection. Proc Natl Acad Sci 91: 1115311157.

Forte P, Lilienfeld BG, Baumann BC, Seebach JD. 2005. Human NK cytotoxicity against porcine cells is triggered by NKp44 and NKG2D. J Immunol 175: 5463-5470.

Fox A, Mountford J, Braakhuis A, Harrison LC. 2001. Innate and adaptive immune responses to nonvascular xenografts: Evidence that macrophages are direct effectors of xenograft rejection. J Immunol 166: 2133-2140.

Fu Y, Yi S, Wu J, Jimenez E, Simond D, Hawthorne WJ, O'Connell PJ. 2008. In vitro suppression of xenoimmune-mediated macrophage activation by human $\mathrm{CD} 4{ }^{+} \mathrm{CD} 25^{+}$regulatory $\mathrm{T}$ cells. Transplantation 86: $865-874$.

Galili U. 2012. Induced anti-non-gal antibodies in human xenograft recipients. Transplantation 93: 11-16.

Galili U, Shohet SB, Kobrin E, Stults CL, Macher BA. 1988. Man, apes, and Old World monkeys differ from other mammals in the expression of $\alpha$-galactosyl epitopes on nucleated cells. J Biol Chem 263: 17755-17762.

Goto M, Tjernberg J, Dufrane D, Elgue G, Brandhorst D, Ekdahl KN, Brandhorst H, Wennberg L, Kurokawa Y, Satomi S, et al. 2008. Dissecting the instant blood-mediated inflammatory reaction in islet xenotransplantation. Xenotransplantation 15: 225-234.

Griesemer AD, Hirakata A, Shimizu A, Moran S, Tena A, Iwaki H, Ishikawa Y, Schule P, Arn JS, Robson SC, et al 2009. Results of Gal-knockout porcine thymokidney xenografts. Am J Transplant 9: 2669-2678.

Griesemer A, Liang F, Hirakata A, Hirsh E, Lo D, Okumi M, Sykes M, Yamada K, Huang CA, Sachs DH. 2010. Occurrence of specific humoral non-responsiveness to swine antigens following administration of GalT-KO bone marrow to baboons. Xenotransplantation 17: 300-312.

Hauschild J, Petersen B, Santiago Y, Queisser AL, Carnwath JW, Lucas-Hahn A, Zhang L, Meng X, Gregory PD, Schwinzer R, et al. 2011. Efficient generation of a biallelic knockout in pigs using zinc-finger nucleases. Proc Natl Acad Sci 108: 12013-12017.

Hauzenberger E, Hauzenberger D, Hultenby K, Holgersson J. 2000. Porcine endothelium supports transendothelial migration of human leukocyte subpopulations: Antiporcine vascular cell adhesion molecule antibodies as species-specific blockers of transendothelial monocyte and natural killer cell migration. Transplantation 69: 1837-1849.

Heeger PS, Lalli PN, Lin F, Valujskikh A, Liu J, Muqim N, Xu Y, Medof ME. 2005. Decay-accelerating factor modulates induction of T cell immunity. J Exp Med 201: 1523-1530.

Hering BJ, Walawalkar N. 2009. Pig-to-nonhuman primate islet xenotransplantation. Transpl Immunol 21: 81-86.

Hering BJ, Wijkstrom M, Graham ML, Hardstedt M, Aasheim TC, Jie T, Ansite JD, Nakano M, Cheng J, Li $\mathrm{W}$, et al. 2006. Prolonged diabetes reversal after intraportal xenotransplantation of wild-type porcine islets in immunosuppressed nonhuman primates. Nat Med 12: 301-303.

Hisashi Y, Yamada K, Kuwaki K, Tseng YL, Dor FJ, Houser SL, Robson SC, Schuurman HJ, Cooper DK, Sachs DH, et al. 2008. Rejection of cardiac xenografts transplanted from $\alpha 1,3$-galactosyltransferase gene-knockout (GalTKO) pigs to baboons. Am J Transplant 8: 2516-2526.

Hodgson R, Christiansen D, Ziolkowski A, Mouhtouris E, Simeonovic CJ, Ierino FL, Sandrin MS. 2011. Prolonged xenograft survival induced by inducible costimulator-Ig is associated with increased Forkhead box $\mathrm{P}^{+}$cells. Transplantation 91: 1090-1097.

Holgersson J, Ehrnfelt C, Hauzenberger E, Serrander L. 2002. Leukocyte endothelial cell interactions in pig to human organ xenograft rejection. Vet Immunol Immunopathol 87: 407-415.

Horvath-Arcidiacono JA, Porter CM, Bloom ET. 2006. Human NK cells can lyse porcine endothelial cells independent of their expression of Gal $\alpha(1,3)$-Gal and killing is enhanced by activation of either effector or target cells. Xenotransplantation 13: 318-327.

Huber-Lang M, Sarma JV, Zetoune FS, Rittirsch D, Neff TA, McGuire SR, Lambris JD, Warner RL, Flierl MA, Hoesel LM, et al. 2006. Generation of C5a in the absence of C3: A new complement activation pathway. Nat Med 12: 682687.

Ide K, Wang H, Tahara H, Liu J, Wang X, Asahara T, Sykes M, Yang YG, Ohdan H. 2007. Role for CD47-SIRP $\alpha$ signaling in xenograft rejection by macrophages. Proc Natl Acad Sci 104: 5062-5066.

Inverardi L, Pardi R. 1994. Early events in cell-mediated recognition of vascularized xenografts: Cooperative interactions between selected lymphocyte subsets and natural antibodies. Immunol Rev 141: 71-93.

Itescu S, Kwiatkowski P, Artrip JH, Wang SF, Ankersmit J, Minanov OP, Michler RE. 1998. Role of natural killer cells, macrophages, and accessory molecule interactions in the rejection of pig-to-primate xenografts beyond the hyperacute period. Hum Immunol 59: 275-286.

Jackson PG, Evans SR. 2000. Intraperitoneal macrophages and tumor immunity: A review. JSurg Oncol 75: 146-154.

Karlsson-Parra A, Ridderstad A, Wallgren AC, Moller E, Ljunggren HG, Korsgren O. 1996. Xenograft rejection 
M. Vadori and E. Cozzi

of porcine islet-like cell clusters in normal and natural killer cell-depleted mice. Transplantation 61: 1313-1320.

Katopodis AG, Warner RG, Duthaler RO, Streiff MB, Bruelisauer A, Kretz O, Dorobek B, Persohn E, Andres $\mathrm{H}$, Schweitzer A, et al. 2002. Removal of anti-Gal $\alpha 1,3 \mathrm{Gal}$ xenoantibodies with an injectable polymer. J Clin Invest 110: $1869-1877$.

Kawahara T, Shimizu I, Ohdan H, Zhao G, Sykes M. 2005 Differing mechanisms of early and late B cell hyporesponsiveness induced by mixed chimerism. Am J Transplant 5: 2821-2829.

Kennett SB, Porter CM, Horvath-Arcidiacono JA, Bloom ET. 2010. Characterization of baboon NK cells and their xenogeneic activity. Xenotransplantation 17: 288-299.

Kiernan K, Harnden I, Gunthart M, Gregory C, Meisner J, Kearns-Jonker M. 2008. The anti-non-gal xenoantibody response to xenoantigens on Gal knockout pig cells is encoded by a restricted number of germline progenitors. Am J Transplant 8: 1829-1839.

Kim CH, Oh K, Kim DE, Lee SB, Yang JH, Lee G, Cho J, Lee DS. 2010. Both CD45RA ${ }^{+}$and $\mathrm{CD} 45 \mathrm{RO}^{+}$human $\mathrm{CD} 4^{+}$ $T$ cells drive direct xenogeneic $\mathrm{T}$-cell responses against porcine aortic endothelial cells. Xenotransplantation 17: 224-232.

Kirchhof N, Shibata S, Wijkstrom M, Kulick DM, Salerno CT, Clemmings SM, Heremans Y, Galili U, Sutherland DE, Dalmasso AP, et al. 2004. Reversal of diabetes in non-immunosuppressed rhesus macaques by intraporta porcine islet xenografts precedes acute cellular rejection. Xenotransplantation 11: 396-407.

Kirk AD, Heinle JS, Mault JR, Sanfilippo F. 1993. Ex vivo characterization of human anti-porcine hyperacute cardiac rejection. Transplantation 56: 785-793.

Klymiuk N, Bocker W, Schonitzer V, Bahr A, Radic T, Frohlich T, Wunsch A, Kessler B, Kurome M, Schilling E, et al. 2012. First inducible transgene expression in porcine large animal models. FASEB J 26: 1086-1099.

Kobayashi T, Taniguchi S, Neethling FA, Rose AG, Hancock WW, Ye Y, Niekrasz M, Kosanke S, Wright LJ, White DJ, et al. 1997. Delayed xenograft rejection of pig-to-baboon cardiac transplants after cobra venom factor therapy. Transplantation 64: 1255-1261.

Koch CA, Khalpey ZI, Platt JL. 2004. Accommodation: Preventing injury in transplantation and disease. J Immunol 172: $5143-5148$.

Konakci KZ, Bohle B, Blumer R, Hoetzenecker W, Roth G, Moser B, Boltz-Nitulescu G, Gorlitzer M, Klepetko W, Wolner E, et al. 2005. $\alpha$-Gal on bioprostheses: Xenograft immune response in cardiac surgery. Eur J Clin Invest 35: $17-23$.

Koshika T, Phelps C, Fang J, Lee SE, Fujita M, Ayares D, Cooper DK, Hara H. 2011. Relative efficiency of porcine and human cytotoxic T-lymphocyte antigen 4 immunoglobulin in inhibiting human $\mathrm{CD}^{+}{ }^{+} \mathrm{T}$-cell responses costimulated by porcine and human B7 molecules. Immunology 134: 386-397.

Kuwaki K, Tseng YL, Dor FJ, Shimizu A, Houser SL, Sanderson TM, Lancos CJ, Prabharasuth DD, Cheng J, Moran K, et al. 2005. Heart transplantation in baboons using $\alpha 1,3-$ galactosyltransferase gene-knockout pigs as donors: Initial experience. Nat Med 11: 29-31.
Kwan WH, van der Touw W, Heeger PS. 2012. Complement regulation of T cell immunity. Immunol Res 54: 247-253.

Lai L, Kolber-Simonds D, Park KW, Cheong HT, Greenstein JL, Im GS, Samuel M, Bonk A, Rieke A, Day BN, et al. 2002. Production of $\alpha-1,3$-galactosyltransferase knockout pigs by nuclear transfer cloning. Science 295: 10891092.

Lam TT, Paniagua R, Shivaram G, Schuurman HJ, Borie DC, Morris RE. 2004. Anti-non-Gal porcine endothelial cell antibodies in acute humoral xenograft rejection of hDAFtransgenic porcine hearts in cynomolgus monkeys. Xenotransplantation 11: 531-535.

Lam TT, Hausen B, Hook L, Lau M, Higgins J, Christians U, Jacobsen W, Baluom M, Duthaler R, Katopodis A, et al. 2005. The effect of soluble complement receptor type 1 on acute humoral xenograft rejection in hDAF-transgenic pig-to-primate life-supporting kidney xenografts. $\mathrm{Xe}$ notransplantation 12: $20-29$.

Le Bas-Bernardet S, Tillou X, Poirier N, Dilek N, Chatelais M, Devalliere J, Charreau B, Minault D, Hervouet J, Renaudin K, et al. 2011. Xenotransplantation of galactosyltransferase knockout, CD55, CD59, CD39, and fucosyltransferase transgenic pig kidneys into baboons. Transplant Proc 43: 3426-3430.

Lilienfeld BG, Garcia-Borges C, Crew MD, Seebach JD. 2006. Porcine UL16-binding protein 1 expressed on the surface of endothelial cells triggers human NK cytotoxicity through NKG2D. J Immunol 177: 2146-2152.

Lin YJ, Hara H, Tai HC, Long C, Tokita D, Yeh P, Ayares D, Morelli AE, Cooper DK. 2008. Suppressive efficacy and proliferative capacity of human regulatory $\mathrm{T}$ cells in allogeneic and xenogeneic responses. Transplantation 86: $1452-1462$.

Lin CC, Cooper DK, Dorling A. 2009. Coagulation dysregulation as a barrier to xenotransplantation in the primate. Transpl Immunol 21: 75-80.

Ljunggren HG, Karre K. 1990. In search of the "missing self": MHC molecules and NK cell recognition. Immunol Today 11: 237-244.

Loveland BE, Milland J, Kyriakou P, Thorley BR, Christiansen D, Lanteri MB, Regensburg M, Duffield M, French AJ, Williams L, et al. 2004. Characterization of a CD46 transgenic pig and protection of transgenic kidneys against hyperacute rejection in non-immunosuppressed baboons. Xenotransplantation 11: 171-183.

Lutz AJ, Li P, Estrada JL, Sidner RA, Chihara RK, Downey SM, Burlak C, Wang ZY, Reyes LM, Ivary B, et al. 2013. Double knockout pigs deficient in $\mathrm{N}$-glycolylneuraminic acid and galactose $\alpha-1,3$-galactose reduce the humoral barrier to xenotransplantation. Xenotransplantation 20: $27-35$.

Macher BA, Galili U. 2008. The Gal $\alpha 1,3$ Gal $\beta 1,4$ GlcNAc-R $(\alpha-\mathrm{Gal})$ epitope: A carbohydrate of unique evolution and clinical relevance. Biochim Biophys Acta 1780: 75-88.

Martin C, Plat M, Nerriere-Daguin V, Coulon F, Uzbekova S, Venturi E, Conde F, Hermel JM, Hantraye P, Tesson L, et al. 2005. Transgenic expression of CTLA4-Ig by fetal pig neurons for xenotransplantation. Transgenic Res 14: 373-384.

McCurry KR, Kooyman DL, Alvarado CG, Cotterell AH, Martin MJ, Logan JS, Platt JL. 1995. Human complement 
regulatory proteins protect swine-to-primate cardiac xenografts from humoral injury. Nat Med 1: 423-427.

McGregor CG, Davies WR, Oi K, Teotia SS, Schirmer JM, Risdahl JM, Tazelaar HD, Kremers WK, Walker RC, Byrne RW, et al. 2005. Cardiac xenotransplantation: Recent preclinical progress with 3-month median survival. J Thorac Cardiovasc Surg 130: 844-851.

McMorrow IM, Comrack CA, Sachs DH, DerSimonian H 1997. Heterogeneity of human anti-pig natural antibodies cross-reactive with the $\operatorname{Gal}(\alpha 1,3)$ Galactose epitope. Transplantation 64: 501-510.

McPherson TB, Liang H, Record RD, Badylak SF. 2000. Gal $\alpha(1,3)$ Gal epitope in porcine small intestinal submucosa. Tissue Eng 6: 233-239.

Menoret S, Plat M, Blancho G, Martinat-Botte F, Bernard P, Karam G, Tesson L, Renaudin K, Guillouet P, Weill B, et al. 2004. Characterization of human CD55 and CD59 transgenic pigs and kidney xenotransplantation in the pig-tobaboon combination. Transplantation 77: 1468-14671.

Mohiuddin MM, Corcoran PC, Singh AK, Azimzadeh A, Hoyt RF Jr, Thomas ML, Eckhaus MA, Seavey C, Ayare D, Pierson RN III, et al. 2012. B-cell depletion extends the survival of GTKO.hCD46Tg pig heart xenografts in baboons for up to 8 months. Am J Transplant 12: 763-771.

Mulder A, Kardol MJ, Arn JS, Eijsink C, Franke ME, Schreuder GM, Haasnoot GW, Doxiadis II, Sachs DH, Smith DM, et al. 2010. Human monoclonal HLA antibodies reveal interspecies crossreactive swine MHC class I epitopes relevant for xenotransplantation. Mol Immuno 47: 809-815.

Muller YD, Seebach JD, Buhler LH, Pascual M, Golshayan D. 2011. Transplantation tolerance: Clinical potential of regulatory T cells. Self Nonself 2: 26-34.

Muller YD, Ehirchiou D, Golshayan D, Buhler LH, Seebach JD. 2012. Potential of T-regulatory cells to protect xenografts. Curr Opin Organ Transplant 17: 155-161.

Naziruddin B, Durriya S, Phelan D, Duffy BF, Olack B, Smith D, Howard T, Mohanakumar T. 1998. HLA antibodies present in the sera of sensitized patients awaiting renal transplant are also reactive to swine leukocyte antigens. Transplantation 66: 1074-1080.

Nishimura T, Onda M, Takao S. 2010. CD4 ${ }^{+} \mathrm{CD} 25^{+}$regulatory $\mathrm{T}$ cells suppressed the indirect xenogeneic immune response mediated by porcine epithelial cell pulsed dendritic cells. Xenotransplantation 17: 313-323.

Ohdan H, Yang YG, Shimizu A, Swenson KG, Sykes M. 1999. Mixed chimerism induced without lethal conditioning prevents T cell- and anti-Gal $\alpha 1,3 \mathrm{Gal}-$ mediated graft rejection. J Clin Invest 104: 281-290.

Padler-Karavani V, Yu H, Cao H, Chokhawala H, Karp F, Varki N, Chen X, Varki A. 2008. Diversity in specificity, abundance, and composition of anti-Neu5Gc antibodies in normal humans: Potential implications for disease. Glycobiology 18: 818-830.

Park JY, Park MR, Kwon DN, Kang MH, Oh M, Han JW, Cho SG, Park C, Kim DK, Song H, et al. 2011. $\alpha 1,3$-Galactosyltransferase deficiency in pigs increases sialyltransferase activities that potentially raise non-gal xenoantigenicity. J Biomed Biotechnol 2011: 560850.

Park JY, Park MR, Bui HT, Kwon DN, Kang MH, Oh M, Han JW, Cho SG, Park C, Shim H, et al. 2012. $\alpha 1,3$-Galactosyltransferase deficiency in germ-free miniature pigs in- creases $\mathrm{N}$-glycolylneuraminic acids as the xenoantigenic determinant in pig-human xenotransplantation. Cell Reprogram 14: 353-363.

Parker W, Bruno D, Holzknecht ZE, Platt JL. 1994. Characterization and affinity isolation of xenoreactive human natural antibodies. J Immunol 153: 3791-3803.

Phelps CJ, Koike C, Vaught TD, Boone J, Wells KD, Chen SH, Ball S, Specht SM, Polejaeva IA, Monahan JA, et al. 2003. Production of $\alpha 1,3$-galactosyltransferase-deficient pigs. Science 299: 411-414.

Phelps CJ, Ball SF, Vaught TD, Vance AM, Mendicino M, Monahan JA, Walters AH, Wells KD, Dandro AS, Ramsoondar JJ, et al. 2009. Production and characterization of transgenic pigs expressing porcine CTLA4-Ig. Xenotransplantation 16: 477-485.

Puga Yung GL, Li Y, Borsig L, Millard AL, Karpova MB, Zhou D, Seebach JD. 2012. Complete absence of the $\alpha$ Gal xenoantigen and isoglobotrihexosylceramide in $\alpha 1,3$ galactosyltransferase knock-out pigs. Xenotransplantation 19: 196-206.

Rogers NJ, Jackson IM, Jordan WJ, Hawadle MA, Dorling A, Lechler RI. 2003. Cross-species costimulation: Relative contributions of CD80, CD86, and CD40. Transplantation 75: 2068-2076.

Saethre M, Schneider MK, Lambris JD, Magotti P, Haraldsen G, Seebach JD, Mollnes TE. 2008. Cytokine secretion depends on $\mathrm{Gal} \alpha(1,3) \mathrm{Gal}$ expression in a pig-to-human whole blood model. J Immunol 180: 6346-6353.

Schmelzle M, Schulte Esch J II, Robson SC. 2010. Coagulation, platelet activation and thrombosis in xenotransplantation. Curr Opin Organ Transplant 15: 212-218.

Schneider MK, Seebach JD. 2008. Current cellular innate immune hurdles in pig-to-primate xenotransplantation. Curr Opin Organ Transplant 13: 171-177.

Schneider MK, Ghielmetti M, Rhyner DM, Antsiferova MA, Seebach JD. 2009. Human leukocyte transmigration across $\mathrm{Gal} \alpha(1,3)$ Gal-negative porcine endothelium is regulated by human CD18 and CD99. Transplantation 87: 491-499.

Scobie L, Padler-Karavani V, Le Bas-Bernardet S, Crossan C, Blaha J, Matouskova M, Hector RD, Cozzi E, Vanhove B, Charreau B, et al. 2013. Long-term IgG response to porcine Neu5Gc antigens without transmission of PERV in burn patients treated with porcine skin xenografts. J Immunol 191: 2907-2915.

Sharma A, Naziruddin B, Cui C, Martin MJ, Xu H, Wan H, Lei Y, Harrison C, Yin J, Okabe J, et al. 2003. Pig cells that lack the gene for $\alpha 1-3$ galactosyltransferase express low levels of the Gal antigen. Transplantation 75: 430-436.

Sheikh S, Parhar R, Al-Mohanna F. 2002. Rapid static adhesion of human naive neutrophil to naive xenoendothelium under physiologic flow is independent of Gal $\alpha 1,3$ gal structures. J Leukoc Biol 71: 932-940.

Shimizu I, Kawahara T, Haspot F, Bardwell PD, Carroll MC, Sykes M. 2007. B-cell extrinsic CR1/CR2 promotes natural antibody production and tolerance induction of anti- $\alpha$ GAL-producing B-1 cells. Blood 109: 1773-1781.

Shimizu A, Hisashi Y, Kuwaki K, Tseng YL, Dor FJ, Houser SL, Robson SC, Schuurman HJ, Cooper DK, Sachs DH, et al. 2008. Thrombotic microangiopathy associated with humoral rejection of cardiac xenografts from $\alpha 1,3$-galac- 
M. Vadori and E. Cozzi

tosyltransferase gene-knockout pigs in baboons. Am J Pathol 172: 1471-1481.

Shimizu A, Yamada K, Robson SC, Sachs DH, Colvin RB. 2012. Pathologic characteristics of transplanted kidney xenografts. J Am Soc Nephrol 23: 225-235.

Singh AK, Seavey CN, Horvath KA, Mohiuddin MM. 2012. Ex-vivo expanded baboon $\mathrm{CD} 4{ }^{+} \mathrm{CD} 25 \mathrm{Hi}$ Treg cells suppress baboon anti-pig $\mathrm{T}$ and $\mathrm{B}$ cell immune response. Xenotransplantation 19: 102-111.

Sommaggio R, Cohnen A, Watzl C, Costa C. 2012. Multiple receptors trigger human NK cell-mediated cytotoxicity against porcine chondrocytes. I Immunol 188: 20752083.

Stevens RB, Platt JL. 1992. The pathogenesis of hyperacute xenograft rejection. Am J Kidney Dis 20: 414-421.

Stone KR, Walgenbach AW, Turek TJ, Somers DL, Wicomb W, Galili U. 2007. Anterior cruciate ligament reconstruction with a porcine xenograft: A serologic, histologic, and biomechanical study in primates. Arthroscopy 23: $411-$ 419.

Tahara H, Ide K, Basnet N, Tanaka Y, Ohdan H. 2010. Determination of the precursor frequency and the reaction intensity of xenoreactive human T lymphocytes. Xenotransplantation 17: 188-196.

Tahiri F, Li Y, Hawke D, Ganiko L, Almeida I, Levery S, Zhou D. 2013. Lack of iGb3 and Isoglobo-series glycosphingolipids in pig organs used for xenotransplantation: Implications for natural killer T-cell biology. J Carbohydr Chem 32: $44-67$.

Tanemura M, Yin D, Chong AS, Galili U. 2000. Differential immune responses to $\alpha$-Gal epitopes on xenografts and allografts: Implications for accommodation in xenotransplantation. J Clin Invest 105: 301-310.

Tanemura M, Ogawa H, Yin DP, Chen ZC, DiSesa VJ, Galili U. 2002. Elimination of anti-Gal B cells by $\alpha-G a l$ ricin1. Transplantation 73: 1859-1868.

Taylor CJ, Tang KG, Smith SI, White DJ, Davies HF. 1998. HLA-specific antibodies in highly sensitized patients can cause a positive crossmatch against pig lymphocytes. Transplantation 65: 1634-1641.

Tazelaar HD, Byrne GW, McGregor CG. 2011. Comparison of Gal and non-Gal-mediated cardiac xenograft rejection. Transplantation 91: 968-975.

Tena A, Turcotte N, Leto Barone A, Arn S, Terlouw S, Dobrinsky J, Sachs D, Hawley R. 2011. Miniature swine expressing human $\mathrm{CD} 47$ to enhance bone marrow engraftment in non-human primates. Xenotransplantation 18: 271.

Thompson P, Badell IR, Lowe M, Cano J, Song M, Leopardi F, Avila J, Ruhil R, Strobert E, Korbutt G, et al. 2011a. Islet xenotransplantation using Gal-deficient neonatal donors improves engraftment and function. Am J Transplant 11: 2593-2602.

Thompson P, Cardona K, Russell M, Badell IR, Shaffer V, Korbutt G, Rayat GR, Cano J, Song M, Jiang W, et al. 2011b. CD40-specific costimulation blockade enhances neonatal porcine islet survival in nonhuman primates. Am J Transplant 11: 947-957.

Tseng YL, Dor FJ, Kuwaki K, Ryan D, Wood J, Denaro M, Giovino M, Yamada K, Hawley R, Patience C, et al. 2004. Bone marrow transplantation from $\alpha 1,3$-galactosyltrans- ferase gene-knockout pigs in baboons. Xenotransplantation 11: 361-370.

van der Windt DJ, Bottino R, Casu A, Campanile N, Cooper DK. 2007. Rapid loss of intraportally transplanted islets: An overview of pathophysiology and preventive strategies. Xenotransplantation 14: 288-297.

van der Windt DJ, Bottino R, Casu A, Campanile N, Smetanka C, He J, Murase N, Hara H, Ball S, Loveland BE, et al. 2009. Long-term controlled normoglycemia in diabetic non-human primates after transplantation with hCD46 transgenic porcine islets. Am J Transplant 9: 2716-2726.

Varki A. 2010. Colloquium paper: Uniquely human evolution of sialic acid genetics and biology. Proc Natl Acad Sci 107: 8939-8946.

Vercellotti GM, Platt JL, Bach FH, Dalmasso AP. 1991. Neutrophil adhesion to xenogeneic endothelium via iC $3 \mathrm{~b}$. J Immunol 146: 730-734.

Vugmeyster Y, Beyer J, Howell K, Combs D, Fielder P, Yang J, Qureshi F, Sandlund B, Kawaguchi L, Dummer W, et al. 2005. Depletion of B cells by a humanized anti-CD20 antibody PRO70769 in Macaca fascicularis. J Immunother 28: $212-219$.

Wallgren AC, Karlsson-Parra A, Korsgren O. 1995. The main infiltrating cell in xenograft rejection is a $\mathrm{CD} 4^{+}$macrophage and not a T lymphocyte. Transplantation 60: 594601.

Weiss EH, Lilienfeld BG, Muller S, Muller E, Herbach N, Kessler B, Wanke R, Schwinzer R, Seebach JD, Wolf E, et al. 2009. HLA-E/human $\beta_{2}$-microglobulin transgenic pigs: Protection against xenogeneic human anti-pig natural killer cell cytotoxicity. Transplantation 87: 35-43.

Wilhite T, Ezzelarab C, Hara H, Long C, Ayares D, Cooper DK, Ezzelarab M. 2012. The effect of Gal expression on pig cells on the human T-cell xenoresponse. Xenotransplantation 19: 56-63.

Wu J, Yi S, Ouyang L, Jimenez E, Simond D, Wang W, Wang Y, Hawthorne WJ, O'Connell PJ. 2008. In vitro expanded human $\mathrm{CD}^{+} \mathrm{CD}_{25}{ }^{+}$regulatory $\mathrm{T}$ cells are potent suppressors of T-cell-mediated xenogeneic responses. Transplantation 85: 1841-1848.

Xu XC, Goodman J, Sasaki H, Lowell J, Mohanakumar T 2002. Activation of natural killer cells and macrophages by porcine endothelial cells augments specific T-cell xenoresponse. Am J Transplant 2: 314-322.

Xu Y, Yang YG, Ohdan H, Ryan D, Harper D, Wu C, KrugerGrey HS, Thall AD, Awwad M, Sykes M. 2006. Characterization of anti-Gal antibody-producing cells of baboons and humans. Transplantation 81: 940-948.

Yamada K, Sachs DH, DerSimonian H. 1995. Human antiporcine xenogeneic $\mathrm{T}$ cell response. Evidence for allelic specificity of mixed leukocyte reaction and for both direct and indirect pathways of recognition. J Immunol 155: 5249-5256.

Yamada K, Yazawa K, Shimizu A, Iwanaga T, Hisashi Y, Nuhn M, O’Malley P, Nobori S, Vagefi PA, Patience C, et al. 2005. Marked prolongation of porcine renal xenograft survival in baboons through the use of $\alpha 1,3$-galactosyltransferase gene-knockout donors and the cotransplantation of vascularized thymic tissue. Nat Med 11: 32-34.

Yamamoto S, Lavelle JM, Vagefi PA, Arakawa H, SamelsonJones E, Moran S, Teranishi K, Kamano C, Fishman J, 
Awwad M, et al. 2005. Vascularized thymic lobe transplantation in a pig-to-baboon model: A novel strategy for xenogeneic tolerance induction and T-cell reconstitution. Transplantation 80: 1783-1790.

Yang YG, deGoma E, Ohdan H, Bracy JL, Xu Y, Iacomini J, Thall AD, Sykes M. 1998. Tolerization of anti-Gal $\alpha 1-3 \mathrm{Gal}$ natural antibody-forming $B$ cells by induction of mixed chimerism. J Exp Med 187: 1335-1342.

Yeh P, Ezzelarab M, Bovin N, Hara H, Long C, Tomiyama K, Sun F, Ayares D, Awwad M, Cooper DK. 2010. Investigation of potential carbohydrate antigen targets for human and baboon antibodies. Xenotransplantation 17: $197-$ 206.
Yi S, Feng X, Hawthorne WJ, Patel AT, Walters AN, O'Connell PJ. 2002. CD4 ${ }^{+} \mathrm{T}$ cells initiate pancreatic islet xenograft rejection via an interferon- $\gamma$-dependent recruitment of macrophages and natural killer cells. Transplantation 73: 437-446.

Yi S, Hawthorne WJ, Lehnert AM, Ha H, Wong JK, van Rooijen N, Davey K, Patel AT, Walters SN, Chandra A, et al. 2003. T cell-activated macrophages are capable of both recognition and rejection of pancreatic islet xenografts. J Immunol 170: 2750-2758.

Zhao Y, Swenson K, Sergio JJ, Arn JS, Sachs DH, Sykes M. 1996. Skin graft tolerance across a discordant xenogeneic barrier. Nat Med 2: 1211-1216. 


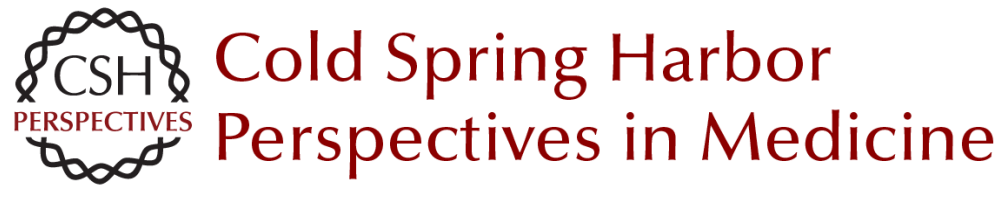

\title{
Immunological Challenges and Therapies in Xenotransplantation
}

\author{
Marta Vadori and Emanuele Cozzi \\ Cold Spring Harb Perspect Med 2014; doi: 10.1101/cshperspect.a015578 originally published online \\ March 10, 2014
}

\section{Subject Collection Transplantation}

Heart Transplantation: Challenges Facing the Field

Makoto Tonsho, Sebastian Michel, Zain Ahmed, et al.

Bioethics of Organ Transplantation Arthur Caplan

Overview of Clinical Lung Transplantation Jonathan C. Yeung and Shaf Keshavjee

Immunological Challenges and Therapies in

Xenotransplantation Marta Vadori and Emanuele Cozzi

Clinical Aspects: Focusing on Key Unique

Organ-Specific Issues of Renal Transplantation Sindhu Chandran and Flavio Vincenti

T-Cell Costimulatory Blockade in Organ Transplantation Jonathan S. Maltzman and Laurence A. Turka

Regulatory T-Cell Therapy in Transplantation: Moving to the Clinic Qizhi Tang and Jeffrey A. Bluestone

Opportunistic Infections--Coming to the Limits of Immunosuppression?

Jay A. Fishman
Overview of the Indications and Contraindications for Liver Transplantation

Stefan Farkas, Christina Hackl and Hans Jürgen Schlitt

Facial and Hand Allotransplantation Bohdan Pomahac, Ryan M. Gobble and Stefan Schneeberger

Induction of Tolerance through Mixed Chimerism David H. Sachs, Tatsuo Kawai and Megan Sykes

Pancreas Transplantation: Solid Organ and Islet Shruti Mittal, Paul Johnson and Peter Friend

Tolerance--Is It Worth It?

Erik B. Finger, Terry B. Strom and Arthur J. Matas

Lessons and Limits of Mouse Models Anita S. Chong, Maria-Luisa Alegre, Michelle L. Miller, et al.

Effector Mechanisms of Rejection Aurélie Moreau, Emilie Varey, Ignacio Anegon, et al.

The Innate Immune System and Transplantation Conrad A. Farrar, Jerzy W. Kupiec-Weglinski and Steven H. Sacks

For additional articles in this collection, see http://perspectivesinmedicine.cshlp.org/cgi/collection/ 